\title{
Mediating Role of Social Media in the Relationship between Reliability, Perceived Usefulness on Online Shopping Behaviour: Building a Conceptual Framework
}

Qaribu Yahaya Nasidi, Muhamad Fazil Bin Ahmad and Isyaku Hassan

To Link this Article: http://dx.doi.org/10.6007/IJARBSS/v11-i2/8834

DOI:10.6007/IJARBSS/v11-i2/8834

Received: 03 December 2020, Revised: 01 January 2021, Accepted: 21 January 2021

Published Online: 20 February 2021

In-Text Citation: (Nasidi et al., 2020)

To Cite this Article: Nasidi, Q. Y., Ahmad, M. F. Bin, \& Hassan, I. (2020). Mediating role of Social Media in the Relationship between Reliability, Perceived Usefulness on Online Shopping Behaviour: Building a Conceptual Framework. International Journal of Academic Research in Business and Social Sciences, 11(2), 385-393.

Copyright: (C) 2021 The Author(s)

Published by Human Resource Management Academic Research Society (www.hrmars.com)

This article is published under the Creative Commons Attribution (CC BY 4.0) license. Anyone may reproduce, distribute, translate and create derivative works of this article (for both commercial and non-commercial purposes), subject to full attribution to the original publication and authors. The full terms of this license may be seen at: http://creativecommons.org/licences/by/4.0/legalcode

Vol. 11, No. 2, 2021, Pg. 385 - 393

Full Terms \& Conditions of access and use can be found at http://hrmars.com/index.php/pages/detail/publication-ethics 


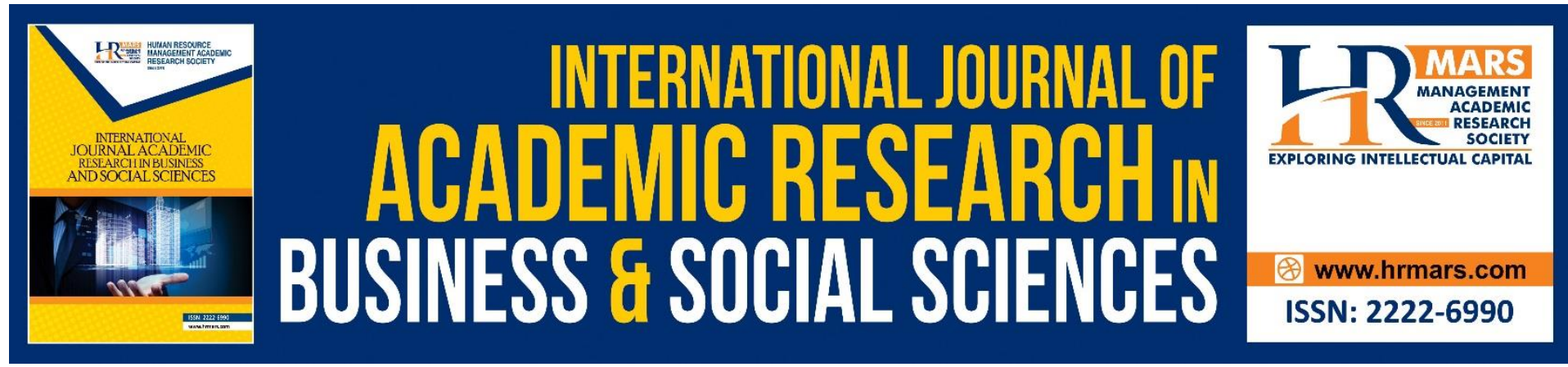

\title{
Mediating Role of Social Media in the Relationship between Reliability, Perceived Usefulness on Online Shopping Behaviour: Building a Conceptual Framework
}

\author{
Qaribu Yahaya Nasidi ${ }^{1,2}$ Muhamad Fazil Bin Ahmad ${ }^{1}$ and \\ Isyaku Hassan ${ }^{1}$ \\ ${ }^{1}$ University Sultan Zainal Abidin (UnisZa), Malaysia, ${ }^{2}$ Ahmadu Bello University, Zaria
}

\begin{abstract}
Over the decades, due to the spread of the internet and the accessibility of digital devices such as laptops, tablets and smartphones, online shopping has grown steadily and become accessible among consumers. In today's world, online shopping is relaxation for individuals engaged in a busy life. Recently, there are changes in the way clients shop from traditional to virtual. While customers prefer to purchase goods from a retail store, internet shoppers feel safer buying online. People who are too involved with their everyday operations are unlikely to spend a lot of time shopping in a physical store. A right choice is to indulge in online shopping. It saves vital time and resources. Social media helps increase awareness about Nigeria's online films and spread the word about online shopping services. Online shopping is getting momentum globally, but the penetration rate in Nigeria is low. Thus, this research tries to propose a conceptual framework of social media's mediating effect on the relationship between Reliability, Perceived Usefulness on Online Shopping Behaviour.
\end{abstract}

Keywords: Online Shopping, Social Media, Digital Devices, Reliability, Perceived Usefulness

\section{Introduction}

Nowadays, the internet is a networking media (Jothi, Neelamalar, \& Prasad, 2011). Still, it is used as a means of transaction between consumer and retailers globally (Li et al., 2021). Internet usage has increased in recent times, and it is useful for distributing and disseminating information about goods and services. With the assistance of information and digital networking technology, customers can buy online using several social media networks and various websites (Bala \& Verma, 2018). This shopping mode can come under different names, such as online shopping, online shopping and online shopping.

According to Murray (2018), Internet shopping is a modern trading pattern that has evolved due to the sheer utility of the internet as a medium or forum for distributing information. The spread of Internet practice and advanced Information Technology has changed business transaction from physical to virtual; thus, an increasing number of online buyers (Gachenge, 2020). Online shopping can be recognized by convenient access, comparatively less corporate 
set-up costs, wide-coverage, freedom of time and interactivity as a modern marketing medium (De Mooij, 2019).

The advances in Internet technologies cause shopping opportunities to be protracted beyond conventional approaches that could require more time. Difficulties of collecting data physically with offline retail strategies are alleviated, and consumers can effectively spend their resources (Al-Fuqaha et al., 2015). For example, as an alternative to physically visiting different stores to compare prices or rely on circular pamphlets in the media, consumers can search and regain information they need via the internet.

Online shopping is becoming omnipresent in Nigeria (Jenyo Gabriel \& Soyoye Kolapo, 2015), because of its relative convenience and in some cases, low prices (Olasanmi, 2019). In light of this, many firms in Nigeria have also started plunging into using these platforms. Notwithstanding, these inspiring online purchasing growth rates in the previous decade, convincing evidence indicates that many consumers, searching different online retail sites, abandon their purchases, making the online stores still small in Nigeria. It's against this background; this research aimed to offer a conceptual framework of social media's mediating effect in the relationship between Reliability, Perceived Usefulness and Online Shopping Behaviour with Nigerian context.

\section{Literature Review \\ Reliability}

Reliability is the degree to which the customer believes in their offerings and online transactions (Shi \& Liao, 2017). This includes distributing the right goods and service after payment status (Xin et al., 2015). The specifics reliability has truth in billing, keeping correct accounts and delivering service at the designated period (Maiyaki \& Mokhtar, 2011). Reliability is almost risk-related, and it is an indicator of customer expectations of whether or not internet businesses should be relied on to deliver on their commitments(Chen et al., 2015; Sadgrove, 2016)

According to Scott (2015), online shoppers need to collect the same product quality and quantity of their purchase within the online firms' time frame. Consequently, to be recognized as reliable online firms, the online shop must deliver and fulfil their promise within the time frame. Equally, Reliability is almost risk-related since it is an indicator of customer expectations of what internet businesses can be relied on to meet their commitments or not (Kumar \& Asawa, 2016; Natarajan et al., 2017; Nili et al., 2019)

\section{Perceived Usefulness}

Perceived usefulness refers to consumers' expectations that modern information technology will boost work efficiency (Kumar \& Asawa, 2016; Singh \& Sinha, 2020). In other words, perceived usefulness is a level to which a person believes that using a system will increase his job routine or performance (Moslehpour et al., 2018; Mou et al., 2017). The perceived usefulness is a significant reason for motivating consumers to embrace online stores.

According to Abd Malik and Annuar (2021), Perceived usefulness refers to the magnitude to which consumers think the online retail firms could enhance value and effectiveness when patronizing product online. The procedures or process in deciding on online shopping communicates to the values and pleasure they observe while shopping (Kuo \& Wu, 2012). Perceived advantages of online shopping are potted as perceived usefulness. The low price and low online browsing charge of exploration will add to perceived benefit (Bölen, 2020; ljaz \& Rhee, 2018; Natarajan et al., 2017). 


\section{Relationship between Reliability and Online Shopping Behaviour}

Some studies established the relationship between reliability, and online shopping behaviour, reliability in some cases stand as the level of truth that consumers have over online firms. Lee and Lin (2005) conducted a study on buyer awareness of e-service quality in online shopping. The results demonstrate that online shopping's reliability dimension is a significant indicator of the overall efficiency of e-service, consumer loyalty and purchasing intentions. Alam and Yasin (2010), examine the features influencing customer satisfaction via online shopping. They identified four critical magnitudes of online shopping. The elements are website design, reliability, product variety and delivery performance. The result revealed that there are significant relationships between reliability and online shopping satisfaction. Kim et al. (2010), investigate the mediating and moderating effect of product involvement and trust towards the website. The study results found that customers with low confidence levels in websites appeared to be more likely to regard interpreted knowledge as mitigating environmental uncertainty. Thus, this study hypothesized that:

$\mathrm{H}_{1}$ : Reliability positively related to online shopping behaviour.

\section{Relationship between Perceived Usefulness and Online Shopping Behaviour}

Perceived usefulness and online shopping behaviour have been documented and established the relationship between the two constructs. A research conducted by (Lim et al., 2014) investigates the perceived usefulness and trust as a factor that influences online shopping behaviour. The study's finding revealed that perceived usefulness is an essential factor contributing to positive online shopping behaviour. Lim et al. (2016), determine the relationship between perceived usefulness and online shopping behaviour. The finding of their study indicates that perceived usefulness is insignificantly influenced by online shopping behaviour. Inegbedion et al. (2016) explore the factors influencing online shopping in the Nigerian context. The researcher examines seven variables as the factors affecting online shopping in Nigeria. The study's findings exposed a substantial influence between perceived usefulness and consumer shopping behaviour in Nigeria. Other researchers like Nagy and Hajdú (2021), Groß and Sohn (2021) established the relationship. Based on the empirical evidence, this study hypothesized that:

$\mathrm{H}_{2}$ : Perceived usefulness positively related to online shopping behaviour.

\section{Relationship between Reliability and Social Media}

The authenticity of social media content is closely related to individuals or organisations who share it. There are some faith and reliability complications in social media simply because any person or company may offer social media details that could be disappointing or untrue. Chung and Austria (2010) researched the messages' effectiveness concerning online shopping value and attitudes towards social media marketing messages. The study's finding revealed that mentality towards social media messages is positively related to social media interaction and information. Lee et al (2011) examine how constructive words affect customers' choice to buy online on online platforms. The study's finding revealed the connection between belief and attitude towards online shopping and the relationship between attitude and intention to shop. Chung and Austria (2012) investigate consumers' motivation behind social media tradition and attitudes towards product message on social media platforms and how they affect consumer online shopping behaviour. Finding explain that interaction and information need affected attitudes towards product messages on social media. This study hypothesized that: 
$\mathrm{H}_{3}$ : Reliability positively related to social media

\section{Relationship between Perceived Usefulness and Social Media}

Wamba (2014), investigate the role of perceived usefulness in social media adoption and use within the workspace. Findings show that perceived usefulness has a significant impact on social media adoption and use in the global model. Yang and Brown (2015), investigate the perceived usefulness of social media among college students in the United States. The research tested a model of illuminating mechanisms connecting social skills to college change through students' understanding of the utility of Facebook and how the site was used. Findings revealed that based on how it was linked to opinions about the utility of various Facebook features, more generous social competence may encourage or hinder college adjustment Garcia and Silva (2017), explore the preference of social media platforms and institutional communication channels by confronting element that forms perceived usefulness and user satisfaction. The findings indicate that respondents perceived more value when using social media technologies to perform activities that information system provided by other medium because of the perceived usefulness. This means that social media skill is part of the routine of modern society in different ways. Potgieter and Naidoo (2017), investigate perceived usefulness and social media-based online brand community. The finding indicates that service quality and social influence explain a more significant part of the social media-based online brand community variance. The effect of perceived usefulness was not statistically significant. This study proposed that

$\mathrm{H}_{4}$ : Perceived usefulness positively related to social media

\section{The Mediating role of Social Media}

Social media is new media that integrate participation and interaction (Marlowe et al., 2017). Social media are internet-based instruments (Neelakandan, Annamalai, Rayen, \& Arunajsmine, 2020) to disseminate and discuss ideas among individuals (Etter et al., 2019). Kuss and Griffiths (2017) opined that social media is a new technology that allows people to share their view, experience, and perceptions. (Chu, 2020)

Social media is an end result or a factor that affects online shopping behaviour (Lim et al., 2017). Social media appeared to be a direct factor for enhancing online shopping behaviour (Hansen et al., 2018). Research that examines the mediating effect of social media in the relationship between reliability and perceived usefulness is scanty in the existing literature, especially in developing countries like Nigeria. Based on those mentioned earlier, this study proposed the framework to examine the relationship between reliability and perceived usefulness on Online Shopping Behaviour. Thus, this study proposed that:

$\mathbf{H}_{5}$ Social media mediate the relationship between reliability, perceived usefulness and online shopping behaviour

\section{Methodology}

This paper thoroughly reviews previous relevant literature to propose a conceptual framework that determines online shopping behaviour (OSB) adoption among Nigerian populace. The variables under study are reliability, perceived usefulness, social media and online shopping behaviour. 


\section{Conceptual Framework}

The literature established that there is significant relationship reliability, perceived usefulness and online shopping behaviour. While studies investigating social media's mediating role in the relationship between reliability, perceived usefulness is not well documented in the existing literature. Therefore, this paper proposed the following framework:

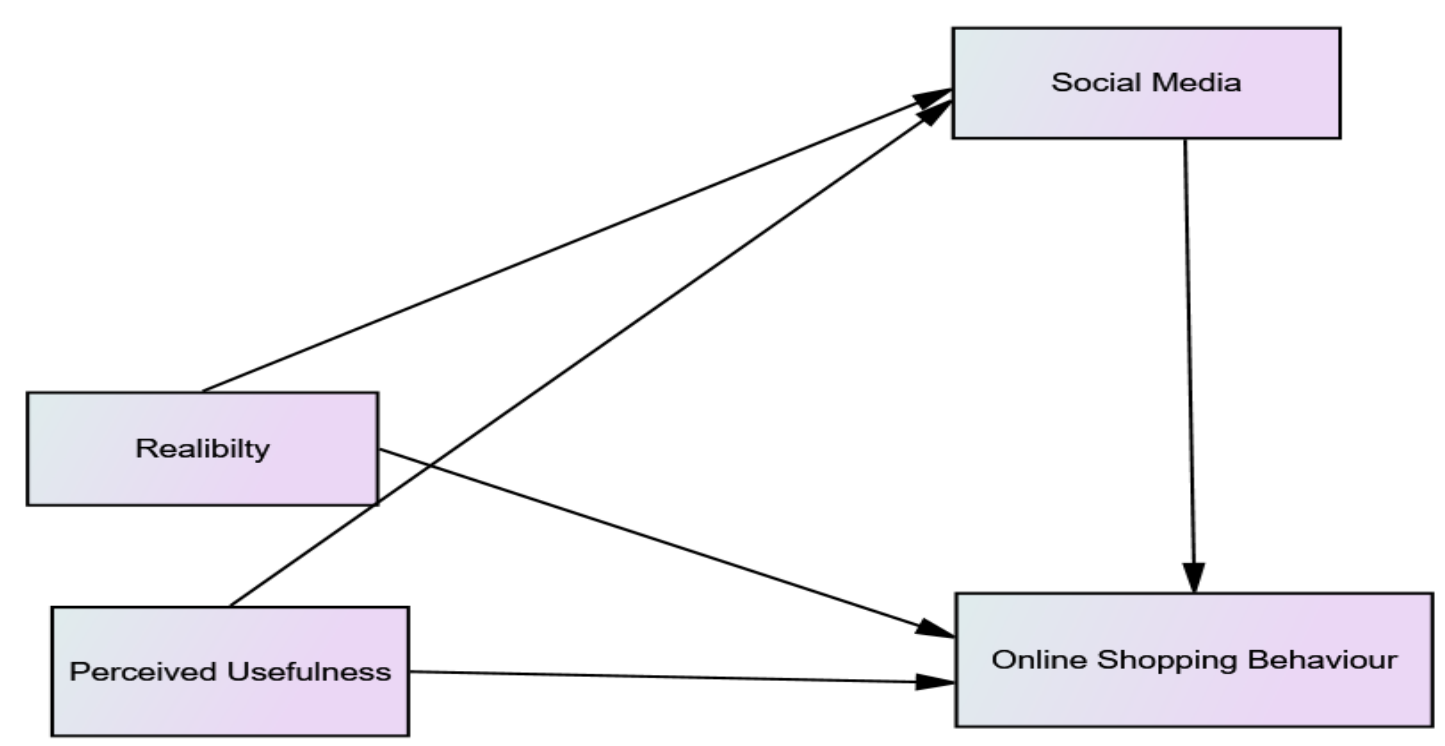

Figure 1: Conceptual Framework of the Study

\section{Conclusion}

This research proposed a framework on the mediating effect of Social Media on the nexus between reliability, perceived usefulness on online shopping behaviour. Several studies have been conducted on the impact of online shopping habits; the integration of social media is expected to add value. However, future research could be undertaken to test the developed conceptual framework. A quantitative method could be used to collect data from online consumers of Nigerian online firms like Jumia. Jiji and the likes. The data would be analysed using SPSS for Exploratory Factor Analysis (EFA) and SEM-AMOS to confirm the variables' relationships. The study made a theoretical contribution by proposing a model representing social media's integration of online shopping. The study will add weight to existing body of 
scientific knowledge by providing good understanding of antecedents of online shopping behaviour.

\section{References}

Abd Malik, A. N., \& Annuar, S. N. S. (2021). The Effect of Perceived Usefulness, Perceived Ease of Use, Reward, and Perceived Risk toward E-Wallet Usage Intention. In Eurasian Business and Economics Perspectives (pp. 115-130). Springer.

Al-Fuqaha, A., Guizani, M., Mohammadi, M., Aledhari, M., \& Ayyash, M. (2015). Internet of things: A survey on enabling technologies, protocols, and applications. IEEE communications surveys \& tutorials, 17(4), 2347-2376.

Alam, S. S., \& Yasin, N. M. (2010). An investigation into the antecedents of customer satisfaction of online shopping. Journal of Marketing Development and Competitiveness, 5(1), 71-78.

Bala, M., \& Verma, D. (2018). A critical review of digital marketing. M. Bala, D. Verma (2018). A Critical Review of Digital Marketing. International Journal of Management, IT \& Engineering, 8(10), 321-339.

Bölen, M. C. (2020). Exploring the determinants of users' continuance intention in smartwatches. Technology in Society, 60, 101209.

Chen, Y., Yan, X., \& Fan, W. (2015). Examining the effects of decomposed perceived risk on consumer's online shopping behavior: A field study in China. Engineering Economics, 26(3), 315-326.

Chu, S. K. W. (2020). Social Media Tools in Experiential Internship Learning. Springer.

Chung, C., \& Austria, K. (2010). Social Media Gratification and Attitude toward Social Media Marketing Messages: A Study of the Effect of Social Media Marketing Messages on Online Shopping Value. Proceedings of the Northeast Business \& Economics Association.

Chung, C., \& Austria, K. P. (2012). Attitudes toward product messages on social media: An examination of online shopping perspectives among young consumers. International Journal of E-Services and Mobile Applications (IJESMA), 4(4), 1-14.

De Mooij, M. (2019). Consumer behavior and culture: Consequences for global marketing and advertising. Sage.

Etter, M., Ravasi, D., \& Colleoni, E. (2019). Social media and the formation of organizational reputation. Academy of Management Review, 44(1), 28-52.

Gachenge, B. (2020). The Effects of Online Customer Experience on E-Commerce Adoption In Nairobi: A Case of Jumia E-Commerce Platform United States International UniversityAfrica].

Garcia, L. S., \& Silva, C. M. C. (2017). Differences between perceived usefulness of social media and institutional channels by undergraduate students. Interactive Technology and Smart Education.

Groß, M., \& Sohn, S. (2021). Understanding the consumer acceptance of mobile shopping: the role of consumer shopping orientations and mobile shopping touchpoints. The International Review of Retail, Distribution and Consumer Research, 31(1), 36-58.

Hansen, J. M., Saridakis, G., \& Benson, V. (2018). Risk, trust, and the interaction of perceived ease of use and behavioral control in predicting consumers' use of social media for transactions. Computers in human behavior, 80, 197-206. 
ljaz, M. F., \& Rhee, J. (2018). Constituents and consequences of Online-shopping in Sustainable E-Business: An experimental study of Online-Shopping Malls. Sustainability, 10(10), 3756.

Inegbedion, H. E., Obadiaru, D. E., \& Bello, V. D. (2016). Factors that influence consumers' attitudes toward internet buying in Nigeria. Journal of Internet Commerce, 15(4), 353375.

Gabriel, J. K., \& Kolapo, S. M. (2015). Online marketing and consumer purchase behaviour: a study of Nigerian firms. British Journal of Marketing Studies, 3(7), 1-14.

Kim, J. U., Kim, W. J., \& Park, S. C. (2010). Consumer perceptions on web advertisements and motivation factors to purchase in the online shopping. Computers in human behavior, 26(5), 1208-1222.

Kumar, V., \& Asawa, A. (2016). A Study on Perceived Risk \& Trust in Online Shopping a Comparative Study Among Various Demographic Groups. Anurag, A Study on Perceived Risk \& Trust in Online Shopping a Comparative Study Among Various Demographic Groups (March 6, 2016).

Kuo, Y.-F., \& Wu, C.-M. (2012). Satisfaction and post-purchase intentions with service recovery of online shopping websites: Perspectives on perceived justice and emotions. International Journal of Information Management, 32(2), 127-138.

Kuss, D. J., \& Griffiths, M. D. (2017). Social networking sites and addiction: Ten lessons learned. International journal of environmental research and public health, 14(3), 311.

Lee, G. G., \& Lin, H. F. (2005). Customer perceptions of e-service quality in online shopping. International Journal of Retail \& Distribution Management.

Lee, M. K., Shi, N., Cheung, C. M., Lim, K. H., \& Sia, C. L. (2011). Consumer's decision to shop online: The moderating role of positive informational social influence. Information \& management, 48(6), 185-191.

Li, F., Larimo, J., \& Leonidou, L. C. (2021). Social media marketing strategy: definition, conceptualization, taxonomy, validation, and future agenda. Journal of the Academy of Marketing science, 49(1), 51-70.

Lim, X. J., Radzol, A., Cheah, J., \& Wong, M. W. (2017). The impact of social media influencers on purchase intention and the mediation effect of customer attitude. Asian Journal of Business Research, 7(2), 19-36.

Lim, Y. J., Osman, A., Salahuddin, S. N., Romle, A. R., \& Abdullah, S. (2016). Factors influencing online shopping behavior: the mediating role of purchase intention. Procedia Economics and Finance, 35(5), 401-410.

Lim, Y. J., Osman, A. B., \& Halim, M. S. B. A. (2014). Perceived usefulness and trust towards consumer behaviors: a perspective of consumer online shopping. Journal of Asian Scientific Research, 4(10), 541.

Maiyaki, A. A., \& Mohd Mokhtar, S. S. (2011). Determinants of customer behavioural responses: A pilot study. International Business Research, 4(1), 193-197.

Marlowe, J. M., Bartley, A., \& Collins, F. (2017). Digital belongings: The intersections of social cohesion, connectivity and digital media. Ethnicities, 17(1), 85-102.

Moslehpour, M., Pham, V. K., Wong, W.-K., \& Bilgiçli, I. (2018). e-purchase intention of Taiwanese consumers: Sustainable mediation of perceived usefulness and perceived ease of use. Sustainability, 10(1), 234.

Mou, J., Shin, D.-H., \& Cohen, J. (2017). Understanding trust and perceived usefulness in the consumer acceptance of an e-service: a longitudinal investigation. Behaviour \& Information Technology, 36(2), 125-139. 
Murray, S. (2018). The Digital Literary Sphere: Reading, Writing, and Selling Books in the Internet Era. Johns Hopkins University Press.

Nagy, S., \& Hajdú, N. (2021). Consumer Acceptance of the Use of Artificial Intelligence in Online Shopping: Evidence from Hungary. Amfiteatru Economic, 23(56).

Natarajan, T., Balasubramanian, S. A., \& Kasilingam, D. L. (2017). Understanding the intention to use mobile shopping applications and its influence on price sensitivity. Journal of Retailing and Consumer Services, 37, 8-22.

Nili, A., Tate, M., \& Johnstone, D. (2019). The process of solving problems with self-service technologies: a study from the user's perspective. Electronic Commerce Research, 19(2), 373-407.

Olasanmi, O. O. (2019). Online shopping and customers' satisfaction in Lagos State, Nigeria. American Journal of Industrial and Business Management, 9(06), 1446.

Potgieter, L. M., \& Naidoo, R. (2017). Factors explaining user loyalty in a social media-based brand community. South African Journal of Information Management, 19(1).

Sadgrove, K. (2016). The complete guide to business risk management. Routledge.

Scott, D. M. (2015). The new rules of marketing and PR: How to use social media, online video, mobile applications, blogs, news releases, and viral marketing to reach buyers directly. John Wiley \& Sons.

Shi, X., \& Liao, Z. (2017). Online consumer review and group-buying participation: The mediating effects of consumer beliefs. Telematics and Informatics, 34(5), 605-617.

Singh, N., \& Sinha, N. (2020). How perceived trust mediates merchant's intention to use a mobile wallet technology. Journal of Retailing and Consumer Services, 52, 101894.

Wamba, S. F. (2014). Perceived usefulness, ease of use and risk in social media adoption within workspace: an empirical study integrating assessment of unobserved heterogeneity in PLS path modeling. Proceedings of the Sixteenth International Conference on Electronic Commerce.

Xin, H., Techatassanasoontorn, A. A., \& Tan, F. B. (2015). Antecedents of consumer trust in mobile payment adoption. Journal of Computer Information Systems, 55(4), 1-10.

Yang, C.-C., \& Brown, B. B. (2015). Factors involved in associations between Facebook use and college adjustment: Social competence, perceived usefulness, and use patterns. Computers in human behavior, 46, 245-253. 